\title{
Postharvest Treatment of 'Florida Prince' Peaches with a Calcium Nanoparticle-Ascorbic Acid Mixture during Cold Storage and Its Effect on Antioxidant Enzyme Activities
}

\author{
${\text { Lo'ay A. A. }{ }^{1} \text { (D) Hamed Ismail }}^{2}$ and Hazem S. Kassem ${ }^{3, *(\mathbb{D})}$ \\ 1 Pomology Department, Faculty of Agriculture, Mansoura University, Mansoura 35516, Egypt; \\ Loay_Arafat@mans.edu.eg \\ 2 Department of Food Science, Ontario Agricultural College, University of Guelph, Guelph, ON N1G 2W1, \\ Canada; ismailh@uoguelph.ca \\ 3 Department of Agricultural Extension and Rural Society, College of Food and Agriculture Sciences, \\ King Saud University, Riyadh 11451, Saudi Arabia \\ * Correspondence: hskassem@ksu.edu.sa; Tel.: +966-58104-5671
}

Citation: A. A., L.; Ismail, H.; Kassem, H.S. Postharvest Treatment of 'Florida Prince' Peaches with a Calcium Nanoparticle-Ascorbic Acid Mixture during Cold Storage and Its Effect on Antioxidant Enzyme Activities. Horticulturae 2021, 7, 499. https://doi.org/10.3390/horticulturae 7110499

Academic Editors: Maria Dulce Carlos Antunes, Custódia Maria Luís Gago and Adriana Guerreiro

Received: 17 September 2021 Accepted: 11 November 2021 Published: 15 November 2021

Publisher's Note: MDPI stays neutral with regard to jurisdictional claims in published maps and institutional affiliations.

Copyright: (c) 2021 by the authors. Licensee MDPI, Basel, Switzerland. This article is an open access article distributed under the terms and conditions of the Creative Commons Attribution (CC BY) license (https:/ / creativecommons.org/licenses/by/ $4.0 /)$.
Abstract: Chilling injury (CI) is a physiological disorder resulting from low storage temperatures that affects the fruit quality and marketing of the 'Florida Prince' peach. In this study, the exogenous application of a mixture of calcium nanoparticles (CaNPs) and ascorbic acid was found to significantly alleviate the symptoms of $\mathrm{CI}$ in peaches during cold storage. Fruits were treated with CaNPs plus different concentrations of ascorbic acid (AA; 0, 3, 6, and $9 \mathrm{mM}$ ). Peaches were immersed in CaNPAA for 15 min before being stored at $4 \pm 1{ }^{\circ} \mathrm{C}$ and $95 \pm 1 \% \mathrm{RH}$ for 30 days. We observed that the $9 \mathrm{mM}$ CaNP-AA treatment lowered the values for the CI index, ion leakage, and malondialdehyde (MDA) content and increased antioxidant enzyme activities (AEAs), such as for ascorbate oxidase (APX), catalase (CAT), superoxide dismutase (SOD), and glutathione reductase (GR). Furthermore, the treatment reduced the accumulation of both $\mathrm{H}_{2} \mathrm{O}_{2}$ and $\mathrm{O}_{2}{ }^{\bullet-}$ and increased the level of DPPH reduction throughout the duration of cold storage. Our results suggest that $9 \mathrm{mM} \mathrm{CaNP}-\mathrm{AA}$ treatment suppresses the incidence of $\mathrm{CI}$ in peach fruit throughout cold storage, possibly because $9 \mathrm{mM}$ CaNP-AA is at least partly involved in enhancing the antioxidant system via its effect on antioxidant substances. The results indicate that applying the $9 \mathrm{mM} \mathrm{CaNP}-\mathrm{AA}$ treatment afforded peaches with enhanced tolerance against cold storage stress.

Keywords: peach; cold storage; quality; calcium nanoparticles; antioxidant enzymes

\section{Introduction}

From the genus Prunus, the Prunus persica L. Batsch cv. 'Florida Prince' peach is the first early stone fruit crop to have been cultivated in Egypt. It displays high acclimation to local ecological conditions. A superior yield and fruit quality in comparison with others are recorded for this peach cultivar [1]. The area used for peach cultivation in Egypt is about $24,707 \mathrm{ha}$, corresponding to a total production of 360,723 tons [2]. Peaches decay easily during marketing processes, losing their value and quality after harvest. This decline occurs for several reasons, such as the rapid ripening of fruits, their sensitivity to mechanical injuries that occur throughout various handling processes, and their susceptibility to rapid infection from fungal diseases [3]. Therefore, for the reasons mentioned above, cold storage is an important way to reduce the rapid ripening of fruits and control the spread of diseases [4]. However, prolonged cold storage of peach fruits leads to biophysical changes in the cell walls that may later manifest as cold injury symptoms [5]. Symptoms of cold injury in peach fruits include the appearance of brown spots that vary in size and shape as well as the collapse of the interior tissue [6]. With an increase in storage duration, there is a tendency for greater development of chilling injury symptoms in fruit, reducing consumer acceptance [7]. 
Numerous studies conducted on CI symptoms have attempted to understand their prevalence and to mitigate their severity, frequently via treatments. Such studies tested the effect of cold storage of fruit [8], heat treatment of fruits to activate the action of antioxidants before cold storage [9], the use of Ultra-Violet (UV-C) [10] or salicylic acid to relieve the symptoms of cold injury [11], and the treatment of fruits with methyl jasmonate [12]. These studies aimed to reduce the occurrence of cold injury symptoms and control the quality of peaches during storage.

Recent research has examined the use of nano-calcium technology in the field of postharvest treatments for diminishing the phenomenon of $\mathrm{CI}$ symptoms during the cold storage of fruits [13]. Strengthening nano-calcium treatment by including antioxidants such as ascorbic acid (AA) plays an active role in countering the CI phenomenon. Generally, CI is directly correlated with the formation of reactive oxygen species (ROS) in fruit tissue throughout the storage period [14]. However, the AA present in plant cells reacts directly with ROS produced in cells [15], especially hydroxyl radicals [16]. Therefore, it increases the tolerance of fruit to the impact of the cold [17]. Furthermore, AA changes the oxidative state of alpha-tocopheroxyl radicals to normalize the action of plasma membranes on the plant cell membrane [18]. It also works to efficiently sustain antioxidant enzyme activity, which creates an equilibrium between the generation of ROS and antioxidants in the cell under chilling stress [19].

Calcium ions $\left(\mathrm{Ca}^{++}\right)$are the main basis of pectin accumulation for supporting the cell wall and middle lamella to produce calcium pectate gel [20]. Calcium ions also balance the cell membrane and thus participate in firmness [21]. However, fruit firmness deteriorates considerably under the highest individually applied calcium chloride doses. Hence, using the authorized dose of calcium chloride $(1 \%)$ is important because the application of high calcium chloride concentrations may cause stress on the tissues and thus a rapid increase in both the respiration rate and ethylene production [22]. Excessive respiration and ethylene production are associated with an increase in enzymatic breakdown, which leads to ripening and senescence [23]. Therefore, the tissues likely become softer than those of the untreated fruits. To the best of our knowledge, no prior studies have examined the role of calcium nanoparticles combined with ascorbic acid in protecting peach fruit during low-temperature storage. Therefore, this paper aims to assess the influence of calcium nanoparticles blended with ascorbic acid on CI increase in the 'Florida Prince' peach cultivar, and investigate the change model in fruit quality, chilling injury, and antioxidant enzyme potential throughout long periods of refrigeration.

\section{Materials and Methods}

\subsection{Fruit Materials and Postharvest Treatments}

The 'Florida Prince' peaches were from a commercial farm in Dakahlia province, Egypt $\left(30.04^{\circ} \mathrm{N}, 31.25^{\circ} \mathrm{E}\right)$. Fruits were picked at commercial maturity (128 days after the full bloom stage) and included if they were free from peel defects and were uniform in size and shape. Fruits (600) were picked and delivered $2 \mathrm{~h}$ after harvesting. They were divided into two main batches. The first batch (300 fruits) was used for physical measurements, i.e., the chilling injury symptoms index, water loss, and fruit skin color (hue angle). This batch was divided into five lots of 60 fruits each for treatments, for which there were three replicates (e.g., $3 \times 20$ fruits). The second batch was used for the chemical analysis and had the same fruit distribution among the treatments as previously described.

\subsection{Synthesis of Metal Calcium Nanoparticles (CaNPs) with Ascorbic Acid (AA)}

Calcium nanoparticles (CaNPs) were prepared according to the procedure reported by Yugandhar and Savithramma [24]. A slight modification was made by adding AA at 3,6, and $9 \mathrm{mM}$ into a solution of $\mathrm{CaCl}(50 \mathrm{mM})$. Using distilled water, all weights of ascorbic acid were blended in a solution of calcium chloride at a concentration of $50 \mathrm{mM}$. The reaction mixture was spun on a checker at 5000 revolutions per minute for $1 \mathrm{~h}$ and then allowed to cool to room temperature for 2-3 days. 
UV-vis spectroscopy was used to characterize the nanoparticles. The reduction of pure $\mathrm{Ca}^{++}$particles and the subsequent topping of calcium nanoparticles were measured using ATI Unicom UV-vis spectroscopic analysis vision software ver. 3.20 by comparing the UV-vis spectra of the response blend at various wavelengths. The combined metal nanoparticles' UV-vis spectra were measured between $240-440 \mathrm{~nm}$. The investigation was successfully conducted at a temperature of $25^{\circ} \mathrm{C}$ using quartz cuvettes with a $1 \mathrm{~cm}$ optical path (Figure 1).

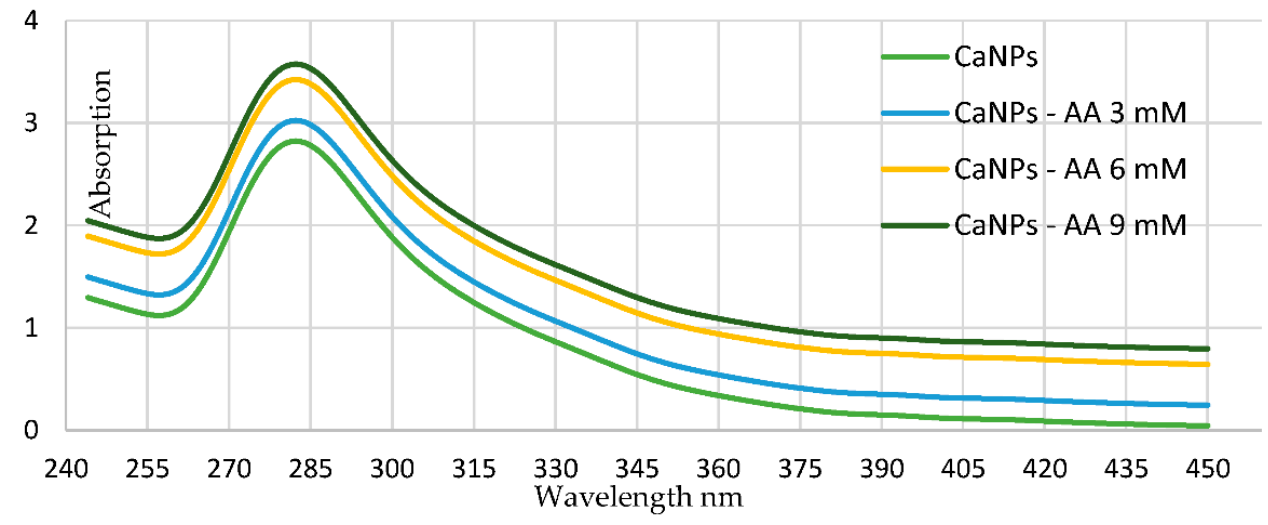

Figure 1. The UV-visible absorption spectra of the structure of calcium nanoparticles (CaNPs) mixed with various combinations of ascorbic acid $(0,3,6$, and $9 \mathrm{mM})$, displaying a peak at $282 \mathrm{~nm}$.

The Zeta Potential test was used to determine the nanoparticles' (NPs) surface state and forecast the nanoparticle solution's long-term stability. The technique was used to define the CaNPs blended with ascorbic acid (AA) surface charge at the Central Laboratory, Electron Microscope Unit, Faculty of Agriculture, Mansoura University, Mansoura, Egypt, using Malvern Instruments Ltd. and Zeta Potential Ver. 2.3. The CaNP-AA mixture has an electrical charge on its surface, attracting a thin layer of ions with opposite directions to the surface. The Zeta Potential of nanoparticles provides information about their properties. Nanoparticles have two layers of ions that move as the solution diffuses. The electric potential at the end of the double layer is referred to as the Zeta Potential of the particles, and it varies between +100 and $100 \mathrm{mV}$. CaNPs containing AA were synthesized and had a Zeta Potential of $-4.74 \mathrm{mV}$ (higher stability). NPs with Zeta Potentials greater than or equal to $+25 \mathrm{mV}$ had a high degree of stability (Figure 2).

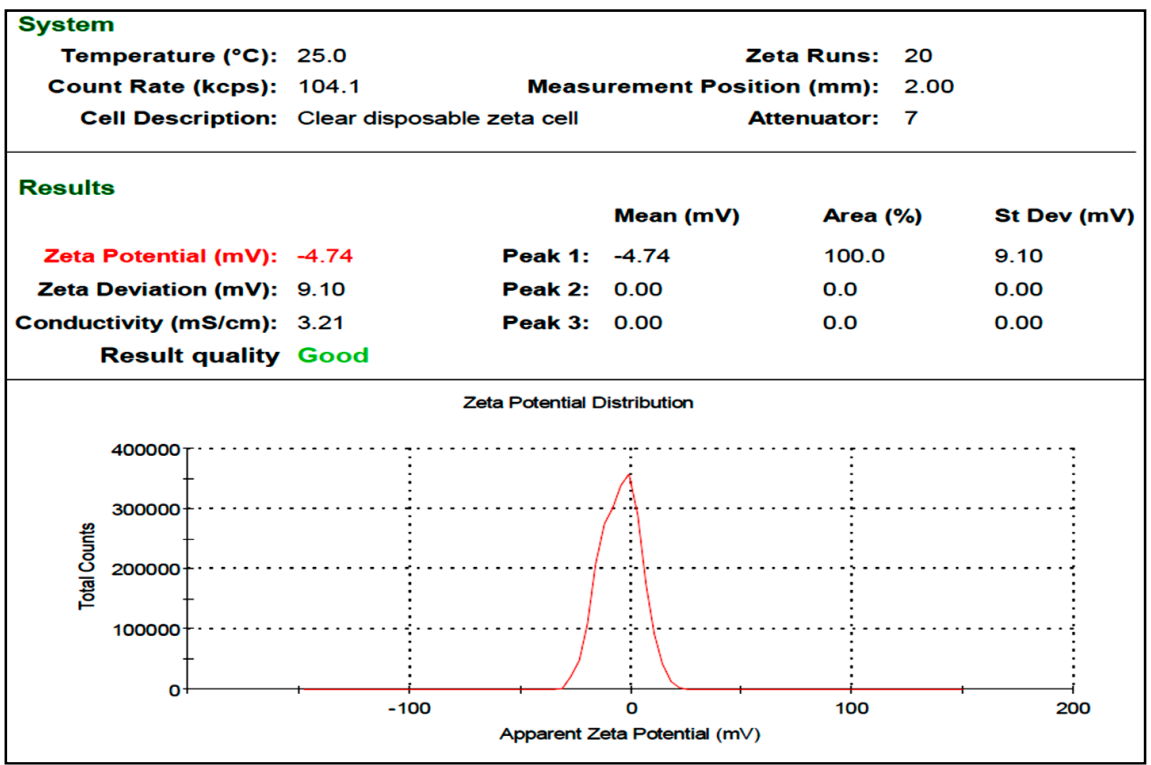

Figure 2. Zeta Potential determination technique for calcium nanoparticles with added ascorbic acid. 
The nanoparticles' characterization was determined using transmission electron microscopy (JEOL TEM-2100) coupled to a CCD camera at a $200 \mathrm{kV}$ acceleration voltage. Nanoparticles were defined according to size, shape, surface area, particle structure, and morphological characteristics. The integrated metal nanoparticles were created by suspending them on copper-coated carbon networks and allowing the dissolvable to dissolve gradually before chronicling the TEM images. TEM measurements were taken at Mansoura University's Central Laboratory, Electron Microscope Unit, Faculty of Agriculture, Mansoura, Egypt (Figure 3).

A

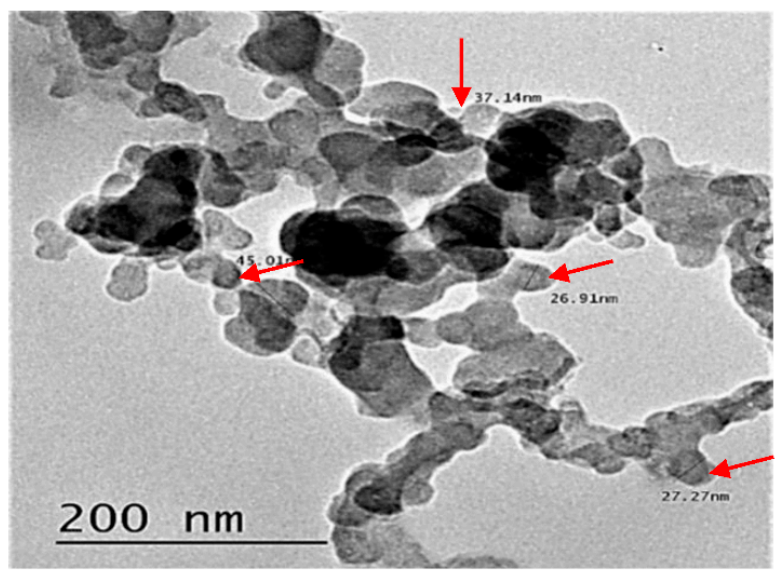

B

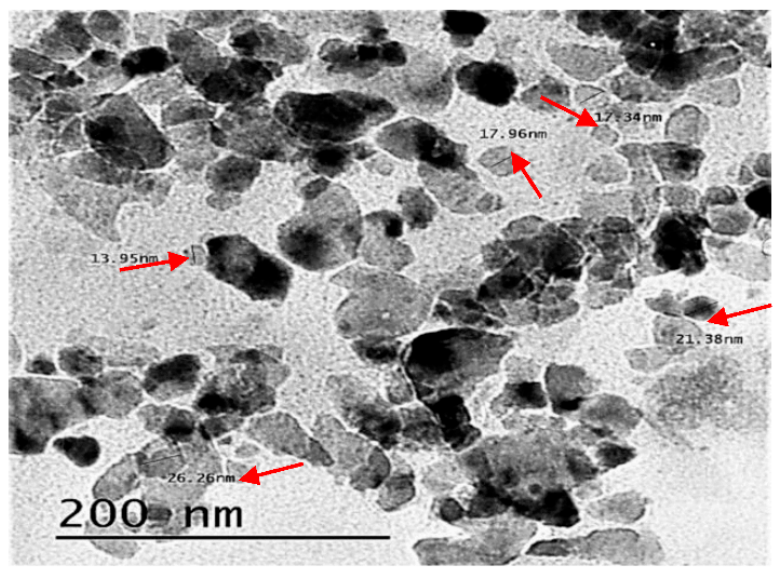

Figure 3. Transmission electron microscopy (TEM) images of the manufactured nanoparticles at $200 \mathrm{~nm}$. The size of the CaNP particles (A) was between 27.27 and $45.01 \mathrm{~nm}$. However, after mixing with ascorbic acid, the CaNPs reached about 13.95-21.38 nm in diameter (B). The particles were orbicular in appearance, and a few were tetragonal. The CaNPs particles tended to aggregate more in isolation than when mixed with ascorbic acid.

\subsection{CaNP-AA Application Protocol}

CaNPs were applied to the batches via five application approaches. The treatments were as follows: control, $0 \mathrm{mM}$ CaNP-AA, $3 \mathrm{mM}$ CaNP-AA, $6 \mathrm{mM}$ CaNP-AA, and $9 \mathrm{mM}$ CaNP-AA. Next, batches were soaked in the CaNP-AA treatments for $15 \mathrm{~min}$ at $4{ }^{\circ} \mathrm{C}$, then placed into cold storage $\left(4 \pm 1^{\circ} \mathrm{C}\right.$ and air relative humidity, $\left.\mathrm{RH} \% 95 \pm 1\right)$ for 30 days.

\subsection{Chilling Injury Index, Water Loss\%, and Fruit Skin Color}

CI symptoms in peaches appear as brown shrunken areas/spots that increase in number and size as the duration of cold storage increases. The CI symptoms were inspected and scored on a scale from 0 (no injury) to 5 (very severe injury) based on necrotic spot area and browning intensity [25]. The CI index was computed according to the following formula:

$$
C I-\text { index }=\sum_{k=5}^{n} \frac{(\text { CI level }) *(\text { Number fruit at this level })}{\text { Total number of fruit }}
$$

Water loss (WL\%) was assessed by the following equation: $W L \%=\left(W_{t=0}-W_{t} / W_{t=0}\right)$ $\times 100$; where $W_{t=0}$ is the initial weight of each fruit and $W_{t}$ is their weight after five days [17]. However, the fruit skin color hue angle measurement was evaluated at intervals throughout the duration of storage by collecting images. To calculate the hue angle of peach, RGB signals were obtained using software ImageJ Ver. $1.43 \mathrm{u}$ (USA), according to Khojastehnazhand et al. [26].

\subsection{Total Soluble Solid Content (SSC\%), Total Acidity (TA\%), and SSC/TA Ratio}

The SSC\% of peach juice was measured with a digital refractometer (PR32 ALAGO Co., Japan) at room temperature and was represented as a percentage. For TA\%, peach 
juice $(20 \mathrm{~mL})$ was used for titration with $\mathrm{NaOH}(0.1 \mathrm{~N})$ [27]. The outcome was presented as a percentage according to the following formula:

$$
T A \%=\frac{[0.1 \mathrm{M} \mathrm{NaOH} * \text { vol. of } \mathrm{NaOH}(\text { in liter }) * 192.43]}{w t \text { of sample }} * 100
$$

where $192.43 \mathrm{~g} / \mathrm{mol}$ is the molecular weight of citric acid.

The SSC/TA ratio was computed to judge peach maturity [25].

\subsection{Fruit Pigments and Fruit Firmness (N)}

The total anthocyanin in the fruit material was extracted using methanol mixed with $1 \%$ hydrochloric acid. After grinding in liquid $\mathrm{N}_{2}$, the samples were incubated at room temperature overnight. The extracts were then centrifuged at $16,000 \times g$ for $16 \mathrm{~min}$ and their absorbance at 530 and $657 \mathrm{~nm}$ was measured using a spectrophotometer set at $421 \mathrm{~nm}$ [28].

The freeze-dried materials were first pulverized in a ball mill to extract the carotene, then $5 \mathrm{~mL}$ of $\mathrm{N}, \mathrm{N}$-dimethylformamide (DMF) was added to $0.8 \mathrm{~g}$ of this powder. To ensure a thorough extraction of carotene, the sample powder was immersed in DMF for 16 min at $4{ }^{\circ} \mathrm{C}$ [29], and then stored at $4{ }^{\circ} \mathrm{C}$ for $16 \mathrm{~h}$. Finally, $1 \mathrm{~mL}$ of the suspension was centrifuged at $16,000 \times g$ for $5 \mathrm{~min}$ at $4{ }^{\circ} \mathrm{C}$ to remove all particles, and the supernatant solution was measured using a spectrophotometer [30].

Fruit firmness measurements were taken using a Zwick Universal Testing Machine equipped with a $60^{\circ}$ conical probe $6.35 \mathrm{~mm}$ in diameter. The apparatus determined the force needed by the mechanical probe to penetrate $8 \mathrm{~mm}$ into the tissue of fruits at a speed of $3 \mathrm{~mm} \mathrm{~s}^{-1}$ [31].

\subsection{Antioxidant Enzyme Activities (AEAs)}

To determine catalase (CAT) activity, fruit pulp $(2 \mathrm{~g})$ was homogenized with $20 \mathrm{~mL}$ of a solution of $100 \mathrm{mM}$ potassium phosphate $\left(\mathrm{KH}_{2} \mathrm{PO}_{4}\right)$. The mixture was centrifuged $(30,000 \times g)$ twice for $25 \mathrm{~min}$ at $4{ }^{\circ} \mathrm{C}$. The clear extraction quantity was utilized for observations of the CAT activity in a final volume of $5 \mathrm{~mL}$ that contained $1 \mathrm{~mL}$ of the catalase extract (400-800 mg protein). A unit of CAT activity was defined as the amount of the compound that could oxidize $1 \mathrm{mM} \mathrm{H}_{2} \mathrm{O}_{2} \min ^{-1}$ at $25^{\circ} \mathrm{C}$ [32].

Ascorbate peroxidase (APX) was isolated from $2 \mathrm{~g}$ of fruit pulp tissue ground with $20 \mathrm{~mL}$ of $50 \mathrm{mM}$ potassium phosphate $\left(\mathrm{KH}_{2} \mathrm{PO}_{4}\right)$. Additionally, EDTA, ascorbic acid (AA, $1 \mathrm{mM}$ ), and polyvinylpolypyrrolidone (PVPP, $1 \%$ ) were added at $5^{\circ} \mathrm{C}$. The materials were mixed and centrifuged twice at $35,000 \times g$ for $30 \mathrm{~min}$ at $4{ }^{\circ} \mathrm{C}$, and the clarified supernatant was utilized to monitor the APX activity in a final quantity of $3 \mathrm{~mL}$. This included $150-300 \mathrm{~mL}$ of the clear fraction ( $40 / 240 \mathrm{mg}$ protein). A unit of APX was characterized as the amount of the compound that oxidized $1 \mathrm{mM}$ of ascorbate $\min ^{-1}$ at $25^{\circ} \mathrm{C}$ [33].

Glutathione reductase (GR) was separated from $1 \mathrm{~g}$ of peach pulp tissue ground in $25 \mathrm{~mL}$ of a $100 \mathrm{mM} \mathrm{KH}_{2} \mathrm{PO}_{4}$ buffer (pH 7.4) containing $0.6 \mathrm{mM}$ EDTA at $5{ }^{\circ} \mathrm{C}$. The mixture was centrifuged twice at $25,000 \times \mathrm{g}$ for $25 \mathrm{~min}$ at $5{ }^{\circ} \mathrm{C}$. An aliquot of the clear supernatant was applied to observe the GR activity in a final volume of $4 \mathrm{~mL}$ [34]. It contained $100 \mathrm{~mL}$ of the accelerator extract (40-80 mg protein). Each GR unit was defined as the amount of accelerator that oxidized $1 \mathrm{mM}$ of NADPH $\mathrm{min}^{-1}$. Moreover, the activity was counted on the standard curve as reported in [35].

Superoxide dismutase (SOD) was isolated from $1 \mathrm{~g}$ of peach pulp tissue ground in $10 \mathrm{~mL}$ of $50 \mathrm{mM} \mathrm{KH_{2 }} \mathrm{PO}_{4}$ with the addition of $1.33 \mathrm{mM}$ of diethylenetriamine penta-acetic acid (DTPA, $\mathrm{C}_{14} \mathrm{H}_{23} \mathrm{~N}_{3} \mathrm{O}_{10}$ ) at $4{ }^{\circ} \mathrm{C}$, then the mixture was centrifuged twice at $30,000 \times g$ for $30 \mathrm{~min}$ at $4{ }^{\circ} \mathrm{C}$. The clear supernatant was used to detect SOD activity [36] in a final volume of $4 \mathrm{~mL}$, which contained $70-80 \mathrm{~mL}$ of the mixture concentrate (24-56 mg of protein). A unit of SOD was described as the quantity of the substances that produced a half-maximal decrease. All the macromolecules were prepared and examined for calculating the catalyst activity [37]. 


\subsection{Lipid Peroxidation, Malondialdehyde (MDA) Accumulation, and Ion Leakage\%}

Peach pulp ( $3 \mathrm{~g}$ ) was ground and combined with $30 \mathrm{~mL}$ of metaphosphoric acid $\left(\mathrm{HPO}_{3}, 5 \%\right)$ and $500 \mu \mathrm{L}$ of butylated hydroxytoluene (2\%) in ethanol; then, the mixture was homogenized. 1,1,3,3-Tetra-ethoxy-propane (Sigma-Aldrich, St. Louis, MO, USA) was used to vary the amount of TBARS from 0 to $20 \mathrm{mM}$ relative to $0-1 \mathrm{mM}$ malondialdehyde (MDA) as a calibration standard to evaluate MDA accumulation product for the peach samples. The stoichiometry of MDA was calculated throughout the acid-heating step of the assay [38].

The ion leakage (IL\%) of all peach samples was measured initially $\left(\mathrm{M}_{0}\right)$ by using an INE-DDSJ-318 conductivity meter. Later, after $3 \mathrm{~h}$, all samples were heated at $100{ }^{\circ} \mathrm{C}$ in a water bath for $30 \mathrm{~min}$ to measure the total leakage after the samples reached room temperature $\left(\mathrm{M}_{1}\right)$ [39]. The percentage of IL\% was calculated by the following formula:

$$
\mathrm{IL} \%=\mathrm{M}_{0} \text { reding after } 3 \mathrm{~h}-\mathrm{M}_{1} \text { (reading after heating) } / \mathrm{M}_{0} \times 100
$$

\subsection{Ethylene and Respiration Assessment}

Ethylene concentrations and $\mathrm{CO}_{2}$ respiration were determined at 5-day intervals in five peaches. For all experimental treatments, fruits were placed and sealed in $1000 \mathrm{~mL}$ glass jars with a 1-h gap between each interval of cold storage duration (in days). Gas chromatography techniques were used to extract gas samples from the headspace atmosphere surrounding the fruit and analyze them for ethylene and carbon dioxide (GC). Ethylene concentrations were determined using a GC-6000 Vega Series from Carlo Erba Ins., Milano, Italy, while $\mathrm{CO}_{2}$ concentrations were determined using a GC PBI-Dansensor Checkmate-9900 from Denmark [40].

\subsection{0. $\mathrm{H}_{2} \mathrm{O}_{2}$ and $\mathrm{O}_{2}{ }^{\bullet-}$ Production Rate and DPPH Reduction}

One gram of fruit tissue was added to $3 \mathrm{~mL}$ of a $\mathrm{KH}_{2} \mathrm{PO}_{4}$ buffer $50 \mathrm{mM}$ (pH 7.8) under cooling at $4{ }^{\circ} \mathrm{C}$. The reagent was combined with polyvinylpyrrolidone (PVP $1 \%$ $w / v$ ) and immediately centrifuged at $10,000 \mathrm{rpm}$ at $4{ }^{\circ} \mathrm{C}$ for $15 \mathrm{~min}$. The $\mathrm{O}_{2}{ }^{\bullet-}$ production rate was determined by observing the development of $\mathrm{NO}_{2}$ from hydroxylamine with the introduction of $\mathrm{O}_{2}{ }^{\bullet-}$ [41]. A linear curve with $\mathrm{NO}_{2}$ was utilized to establish the $\mathrm{O}_{2}{ }^{\bullet-}$ formation rate from the response of $\mathrm{O}_{2}{ }^{\bullet-}$ with hydroxylamine. $\mathrm{O}_{2}{ }^{\bullet-}$ production was determined as nmol $\mathrm{min}^{-1} \mathrm{~g}^{-1} \mathrm{FW}$.

In the $\mathrm{H}_{2} \mathrm{O}_{2}$ assay, $1 \mathrm{~g}$ of the fruit pulp sample was added to $6 \mathrm{~mL}$ of $100 \%\left(\mathrm{CH}_{3}\right)_{2} \mathrm{CO}$ and immediately centrifuged at $10,000 \times \mathrm{g}$ for $15 \mathrm{~min}$ at $4{ }^{\circ} \mathrm{C}$, then $1 \mathrm{~mL}$ of the clarified supernatant was combined with $0.1 \mathrm{~mL}$ of $5 \% \mathrm{Ti}\left(\mathrm{SO}_{4}\right)_{2}$ and $0.2 \mathrm{~mL}$ of a $\mathrm{NH}_{4} \mathrm{OH}$ solution. The hydrogen peroxide sample was accelerated, and the residue was reduced by adding $4 \mathrm{~mL}$ of $2 \mathrm{M} \mathrm{H}_{2} \mathrm{SO}_{4}$ after centrifugation at $10,000 \times g$ for $20 \mathrm{~min}$, then the absorbance was quantified on a photometer at $415 \mathrm{~nm}$. The $\mathrm{H}_{2} \mathrm{O}_{2}$ content was calculated from a standard curve and the fixation rate was shown as $\eta \mathrm{mol} \mathrm{g}^{-1} \mathrm{FW}$ [42].

The inhibitory activity of DPPH was examined in the peach pulp sample and the dismutation of radical activity technique was applied. The scavenging results of flavedo samples of DPPH radicals were given as percentages. In brief, a $2 \mathrm{~mL}$ sample of peach extract (with methanol) was combined with $2 \mathrm{~mL}$ of $0.16 \mathrm{mM}$ DPPH methanolic solvent. Afterward, samples were shaken for $1 \mathrm{~min}$ and stored for $30 \mathrm{~min}$ at room temperature in dark conditions. Subsequently, samples were evaluated on a photometer at a wavelength absorbance of $517 \mathrm{~nm}$. The final amount of the DPPH radical was assumed by applying the formula of [43].

\subsection{Statistical Analysis}

The experiment was conducted during two growth seasons (2018-2019) using the CoStat software package (Ver. 6.303; 789 Lighthouse Ave PMB 320, Monterey, CA 93940, USA). The chilling injury, water loss, and peach skin color profile were analyzed in a randomized complete block design for the effect of fruit color maturity stages (applied to the same fruit 
throughout the storage period). A factorial analysis displayed the main comparisons and the interaction effect of storage time and CaNP-AA under refrigeration. The appropriate significant differences among CaNP-AA treatments were tested by utilizing Duncan's multiple range test at the $5 \%$ level.

\section{Results}

\subsection{Synthesis of Metal Calcium Nanoparticles (CaNPs)}

We observed that the formation of calcium nanoparticles (CaNPs) blended with ascorbic acid at different concentrations was synthesized, and we confirmed treatments at a peak at $282 \mathrm{~nm}$ by UV-visible absorption spectra (Figure 1). Another technique to prove the formation of nanoparticles was using the Zeta Potential test for calcium nanoparticles with added ascorbic acid (Figure 2). To be certain, we used Transmission Electron Microscopy (TEM) images at $200 \mathrm{~nm}$. The size of the CaNP particles (Figure 3A) was between 27.27 and $45.01 \mathrm{~nm}$. However, after mixing with ascorbic acid, the CaNPs reached about 13.95-26.26 nm in diameter (Figure 3B).

\subsection{Index, Water Loss \%, and Peach Skin Color}

Figure 4 shows the changes in the CI index, water loss, and peach skin color $\left(h^{\circ}\right)$ as physical features of peach quality throughout a cold storage period of several weeks. CaNPAA treatments had a significant influence when studied as a factor. Regarding the various CaNP-AA applications, a significantly greater increase in CI incidence and water loss occurred, while peach skin color declined, in the untreated fruit compared with fruit treated throughout the 30 days. Nevertheless, fruit subjected to the $9 \mathrm{mM}$ CaNP-AA treatment presented significantly lower CI incidence and water loss and the highest preservation of peach skin color $\left(h^{\circ}\right)$ compared with other CaNP-AA treatments throughout the storage period. Moreover, the $9 \mathrm{mM}$ CaNP-AA treatment minimized CI incidence over the full storage period (30 days). This began on the 20th day (1.01), then increased slightly up until the end of storage (1.19). The outcomes indicated a reduction in the rate of water loss $(19.57 \%)$ and a slight decline in the skin color of the fruit $\left(h^{\circ}=75.31\right)$ on the 30th day of the cold storage period. The change in physical parameters could be due to the cold temperature stress effects, which enhanced the formation of reactive oxygen species (ROS).

\subsection{Total Soluble Solids (SSC\%), Total Acidity (TA\%), and SSC/TA Ratio}

Figure 5 depicts the differentiation in chemical quality, i.e., SSC $\%$, TA\%, and SSC/TA ratio, as a function of storage duration in days for 'Florida Prince' peach. Evidently, SSC \% increased significantly in the control fruit during the storage period. However, the CaNP-AA at $9 \mathrm{mM}$ treatments presented a different trend. We observed the lowest changes in SSC\% compared to untreated and treated fruit. The chemical quality elements revealed a significant interaction ( $p<0.001)$ when storage time (days) and CaNP-AA treatments were examined.

The chemical quality results for fruit treated with the control treatment showed a gradual increase in SSC \% and the SSC/TA ratio throughout the 30 days. Nevertheless, reductions in total TA\% throughout storage duration in fruit treated with $9 \mathrm{mM} \mathrm{CaNP}-\mathrm{AA}$ were seen. This produced the lowest changes in both SSC and the SSC/TA ratio throughout the cold storage period compared with other treatments and the initial values at harvest time, with $11.82 \%$ SSC and an SSC/TA ratio of $12.23 \%$. However, a stable TA value $(0.960 \%)$ was maintained on the 30th day of the storage period compared with the initial value $(1.016 \%)$ at harvest time.

\subsection{Fruit Pigments (Anthocyanin and Carotene) and Fruit Firmness (N)}

Figure 6 displays the variation in fruit pigment (i.e., anthocyanin (peel; $\mathrm{mg} 100 \mathrm{~g}^{-1}$ FW) and carotene (pulp; $\left.\mu \mathrm{g} 100 \mathrm{~g}^{-1} \mathrm{FW}\right)$ ) and firmness (N) as a function of storage duration in days for 'Florida Prince' peach. Evidently, both pigments decreased significantly in all CaNP-AA mixtures and control fruit throughout the storage period, as did fruit firmness. The $9 \mathrm{mM}$ CaNP-AA treatment significantly reduced the fruit pigment degradation and 
firmness throughout 30 days compared with the initial value at harvest time. Fruit pigments

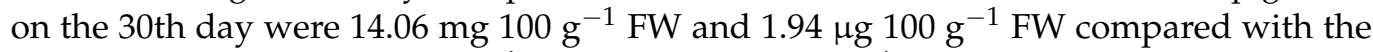

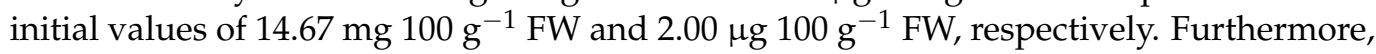
fruit firmness was recorded at $61.87 \mathrm{~N}$, compared with an initial value of $63.26 \mathrm{~N}$.
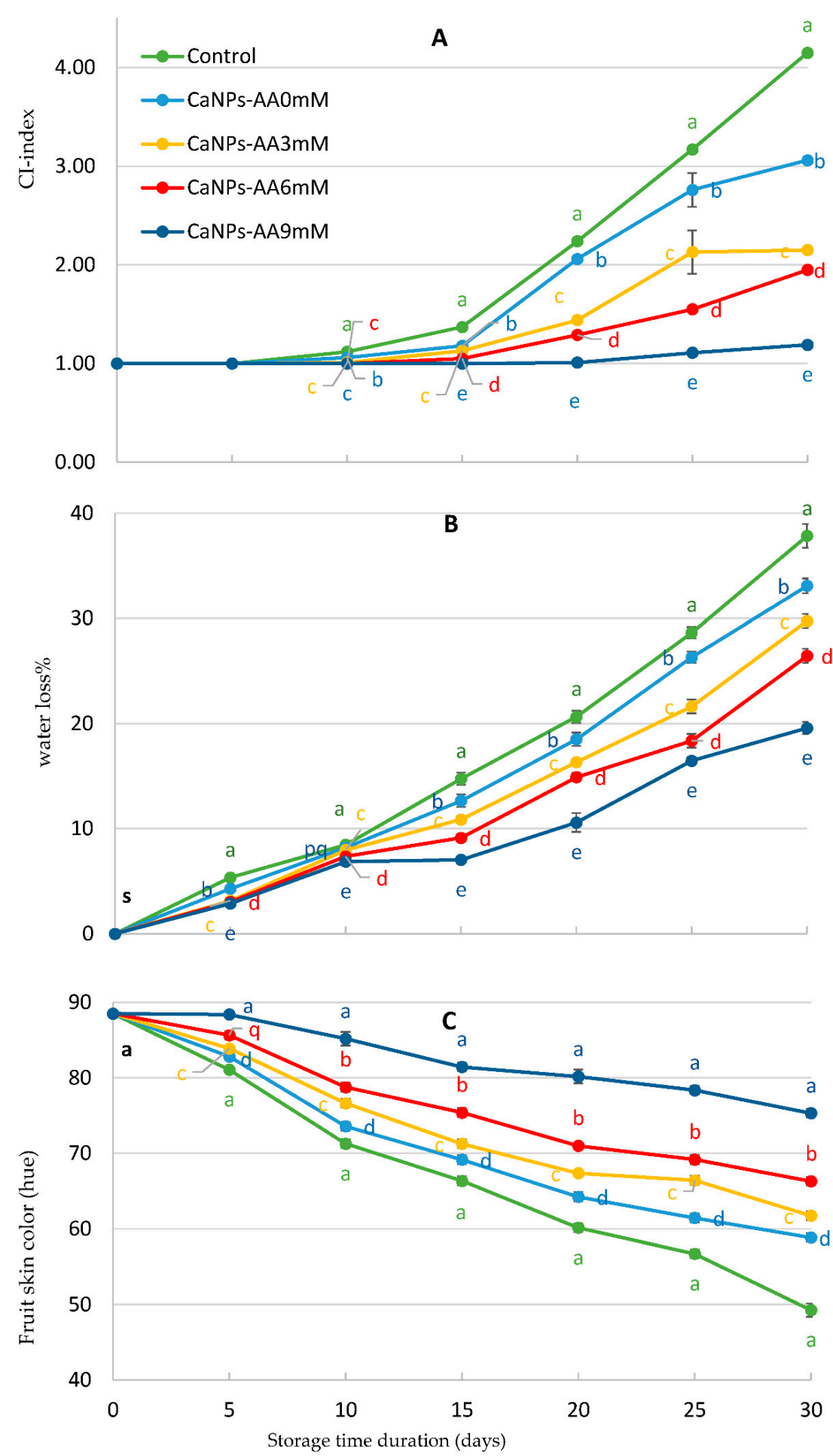

Figure 4. The chilling injury index (A), water loss percentage (B), and fruit skin color (hue) (C) of 'Florida Prince' peaches immersed in CaNPs mixed with ascorbic acid at different concentrations $(0$, $3,6$, and $9 \mathrm{mM})$ and stored at a low temperature $\left(4^{\circ} \mathrm{C}\right.$ and $\left.95 \% \mathrm{RH}\right)$ for 30 days. Error bars represent standard errors and different letters indicate significant differences at $p \leq 0.05$ among treatments for each storage period. 

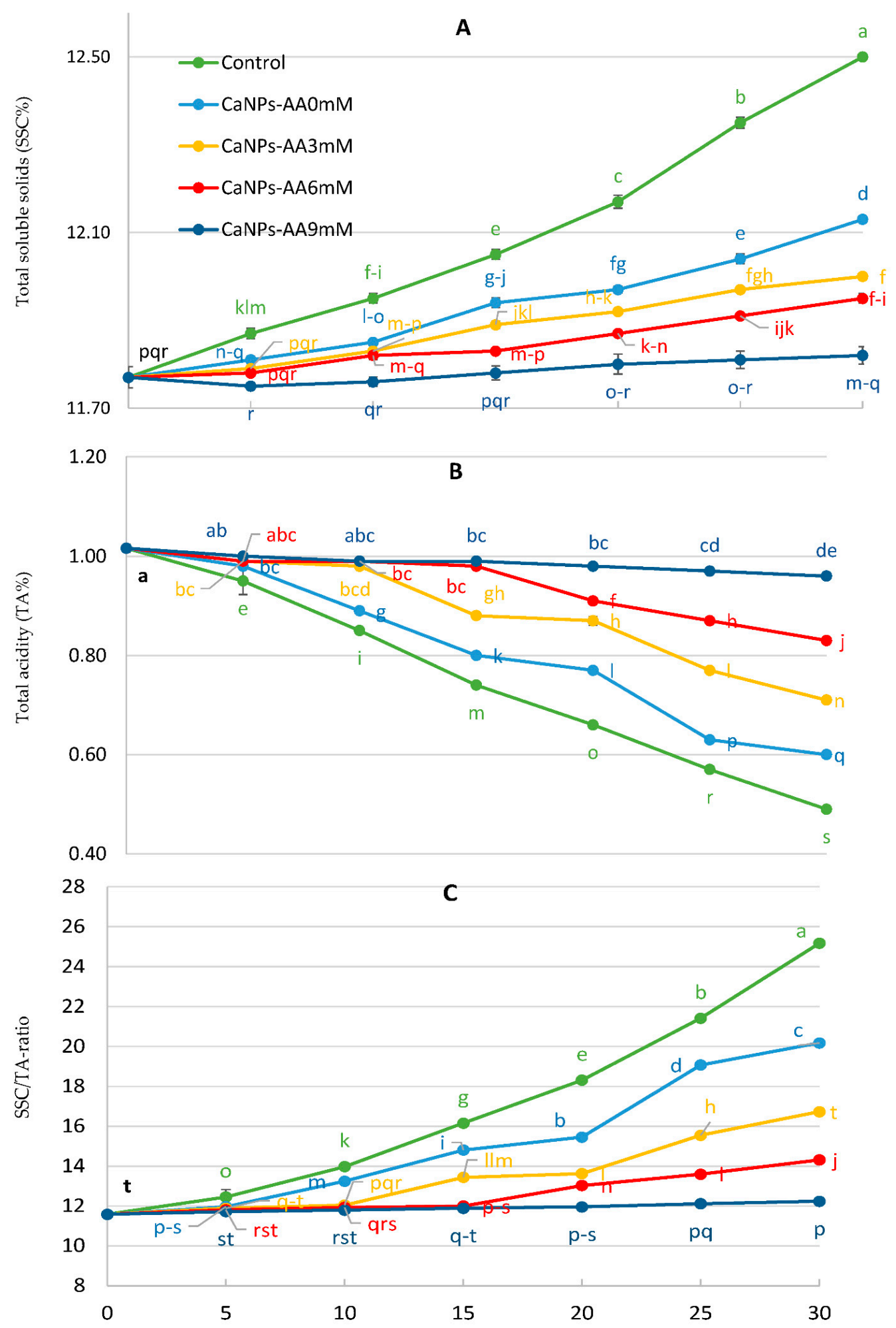

Storage time (days)

Figure 5. The total soluble solid content (SSC\%) (A), total acidity percentage (TA\%) (B), and SSC/TA ratio (C) of 'Florida Prince' peaches immersed in CaNPs mixed with ascorbic acid at different concentrations $(0,3,6$, and $9 \mathrm{mM})$ and stored at a low temperature $\left(4{ }^{\circ} \mathrm{C}\right.$ and $\left.95 \% \mathrm{RH}\right)$ for 30 days. Error bars represent standard errors and different letters indicate significant differences at $p \leq 0.05$ among treatments for each storage period. 

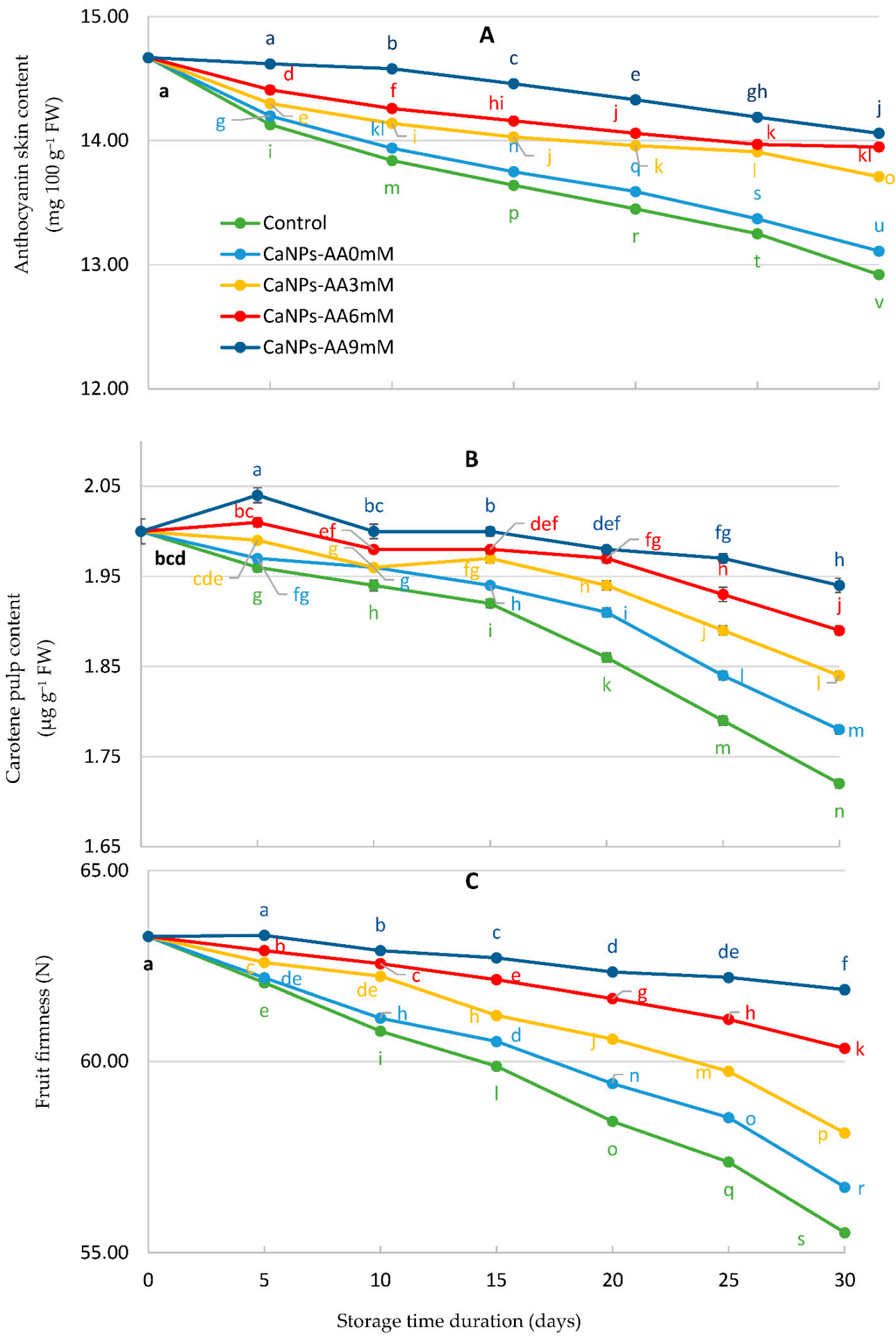

Figure 6. Fruit pigments (i.e., anthocyanin (A) and carotene (B)) and fruit firmness (C) of 'Florida Prince' peaches immersed in CaNPs mixed with ascorbic acid at different concentrations (0, 3, 6, and $9 \mathrm{mM}$ ) and stored at a low temperature $\left(4{ }^{\circ} \mathrm{C}\right.$ and $\left.95 \% \mathrm{RH}\right)$ for 30 days. Error bars represent standard errors and different letters indicate significant differences at $p \leq 0.05$ among treatments for each storage period.

\subsection{Antioxidant Enzyme Activity (AEA)}

Figure 7 displays the antioxidant enzyme activities (AEAs) as a function of storage time in weeks. Apparently, the AEAs displayed a significant interaction at 5\% when the CaNP-AA treatments and storage time duration (days) were considered as an experimental factor. 

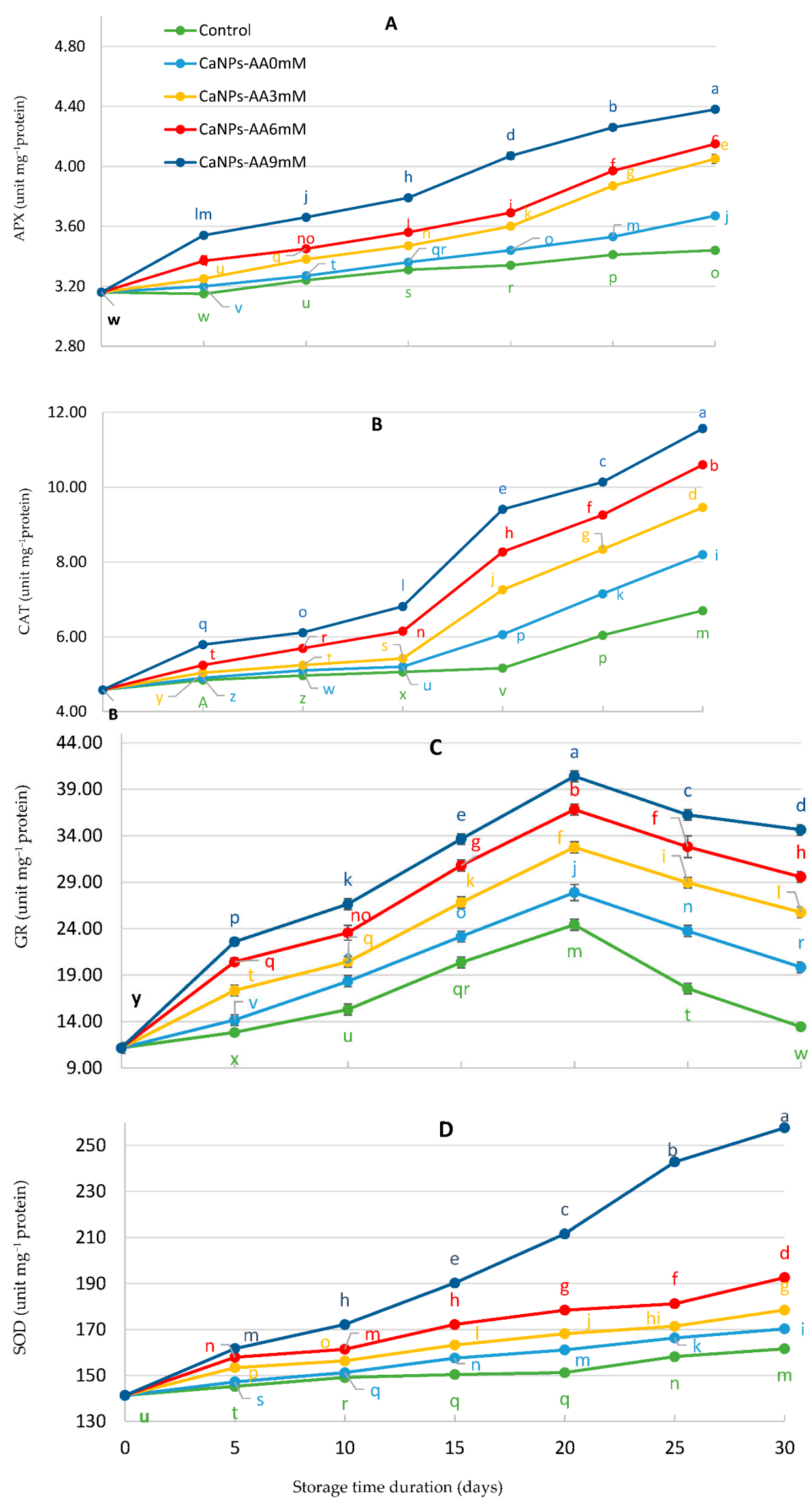

Figure 7. The AEAs, such as APX (A), CAT (B), GR (C), and SOD (D), of 'Florida Prince' peaches immersed in CaNPs mixed with ascorbic acid at different concentrations $(0,3,6$, and $9 \mathrm{mM})$ and stored at a low temperature $\left(4{ }^{\circ} \mathrm{C}\right.$ and $\left.95 \% \mathrm{RH}\right)$ for 30 days. Error bars represent standard errors and different letters indicate significant differences at $p \leq 0.05$ among treatments for each storage period. 
The AEAs continued to increase differently until the end of the storage period. The changes in overall levels of AEAs for all treatments increased slightly throughout the first 20 days, then they became different up to the end of the cold storage period for all treatments.

However, the GR activity increased up to the 20th day and then declined in all treatments until the end of the experiment. Obviously, exogenous treatment with $9 \mathrm{mM}$ CaNP-AA increased the AEAs in peach. The activity increased (APX, 4.38; CAT, 11.57; SOD 257.68) until the 30th day, but GR (40.40) increased up to the 20th day and then declined (34.63 units $\mathrm{g}^{-1}$ protein) until the end of the experiment.

\subsection{Estimation of Malondialdehyde (MDA), Ion Leakage (IL\%), Ethylene Production, and Respiration Rate}

In peach pulp, MDA accumulation and IL\% significantly $(p>0.01)$ and dramatically increased throughout the duration of storage, dependent on the CaNP-AA treatment (Figure 8). A significant interaction among storage factors, storage duration (weeks), and CaNP-AA treatment was considered as an experimental factor. MDA content and IL\% clearly increased in the CaNP-AA treatments compared with the initial values. Furthermore, differences among the CaNP-AA treatments appeared on the 10th day and became more pronounced during the storage duration until the end of the experiment. Certainly, the lowest values of MDA and IL\% were identified in peaches treated with $9 \mathrm{mM} \mathrm{CaNP}-\mathrm{AA}$ (MDA $=0.24$ and IL $=23.37 \%$ ) on the 30th day of the storage period compared with other treatments. However, the control treatment exhibited the highest accumulation of MDA (0.44) and IL (44.85\%) in the same time interval. Moreover, the ethylene evolution and respiration rate in peach increased gradually and independently in the CaNP-AA treatments up to the maximum peak on the 10th and 5th days of storage. Both then declined until the end of storage time. However, it can be seen in Figure 5 that respiration showed an increase in $\mathrm{CO}_{2}$ rate until the end of storage. The increases in $\mathrm{CO}_{2}$ were independent and based on the $\mathrm{CaNP}-\mathrm{AA}$ treatments. However, lower ethylene production and $\mathrm{CO}_{2}$ over the 30 days was observed in the control.
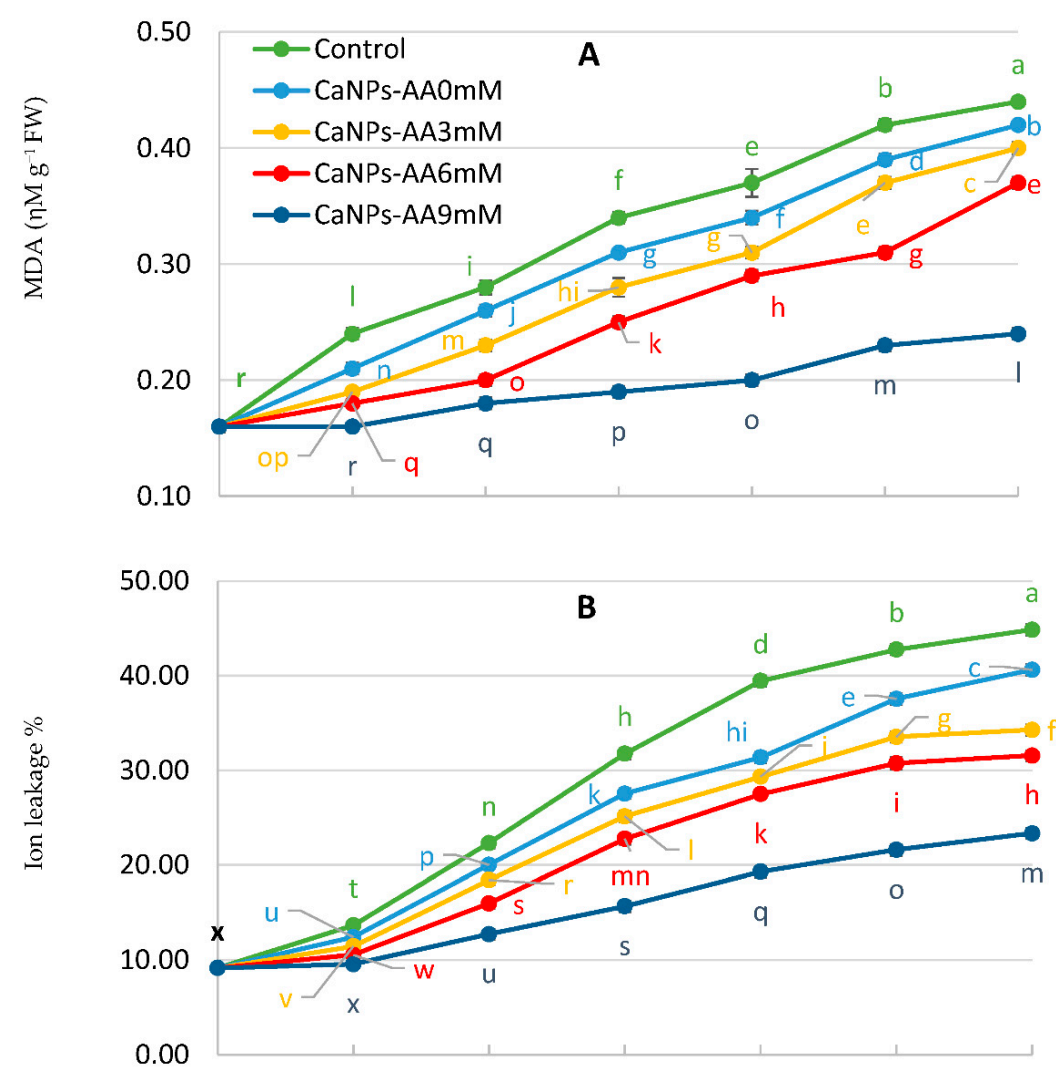

Figure 8. Cont. 

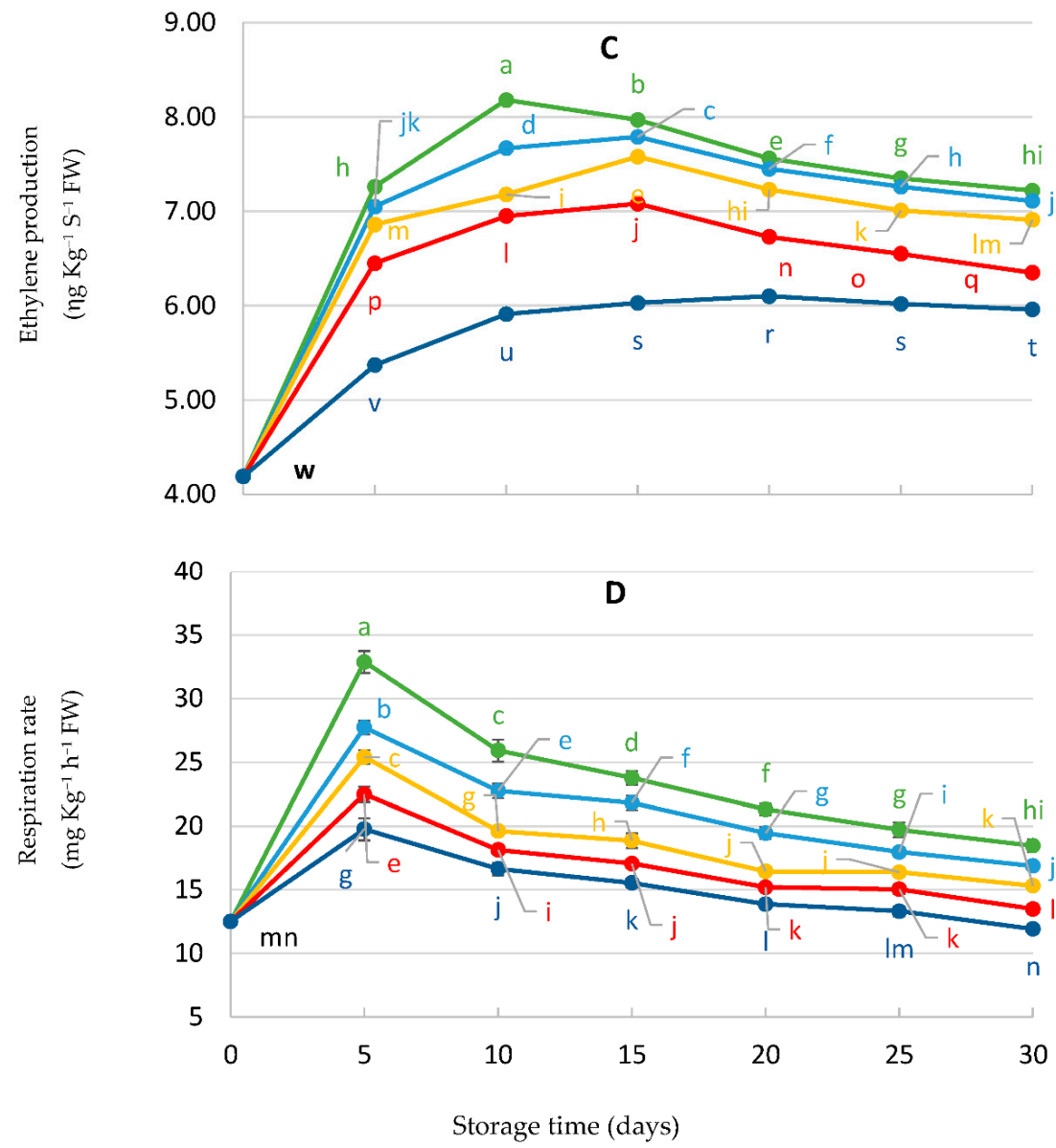

Figure 8. MDA (A), IL\% (B), ethylene (C), and respiration rate (D) of 'Florida Prince' peaches immersed in CaNPs mixed with ascorbic acid at different concentrations (0, 3, 6, and $9 \mathrm{mM})$ and stored at a low temperature $\left(4{ }^{\circ} \mathrm{C}\right.$ and $\left.95 \% \mathrm{RH}\right)$ for 30 days. Error bars represent standard errors and different letters indicate significant differences at $p \leq 0.05$ among treatments for each storage period.

\section{7. $\mathrm{H}_{2} \mathrm{O}_{2}$ and $\mathrm{O}_{2}{ }^{\bullet-}$ Production and DPPH Reduction}

Differences in $\mathrm{H}_{2} \mathrm{O}_{2}$ and $\mathrm{O}_{2}{ }^{\bullet-}$ generation rates and antioxidant performance (utilizing the DPPH technique) could be seen as a function of time in days. The parameters produced a significant effect $(p<0.003)$ when the storage time and CaNP-AA applications were used as experimental factors (Figure 9).

$\mathrm{H}_{2} \mathrm{O}_{2}$ and $\mathrm{O}_{2}{ }^{\bullet-}$ generation in peach pulp increased continuously from the time of fruit collection up to the 30th day of the experiment. Consequently, increases and differences were independently associated with CaNP-AA applications on the 30th day of storage time. The $9 \mathrm{mM}$ CaNP-AA treatment produced the lowest $\mathrm{H}_{2} \mathrm{O}_{2}\left(0.12 \mathrm{mM} \mathrm{min}^{-1} \mathrm{~g}^{-1}\right.$ $\mathrm{FW})$ and $\mathrm{O}_{2}{ }^{\bullet-}\left(0.34 \mathrm{mM} \mathrm{g}^{-1} \mathrm{FW}\right)$ amounts throughout the storage period compared with different CaNP-AA treatments on the 30th day. The assessment of AEAs by utilizing the DPPH decrease demonstrated that their activity improved spontaneously and slowly in all CaNP-AA treatments throughout the storage period. In any case, the control displayed the greatest reduction in DPPH (41.86\%) on the 30th day of the trial. 

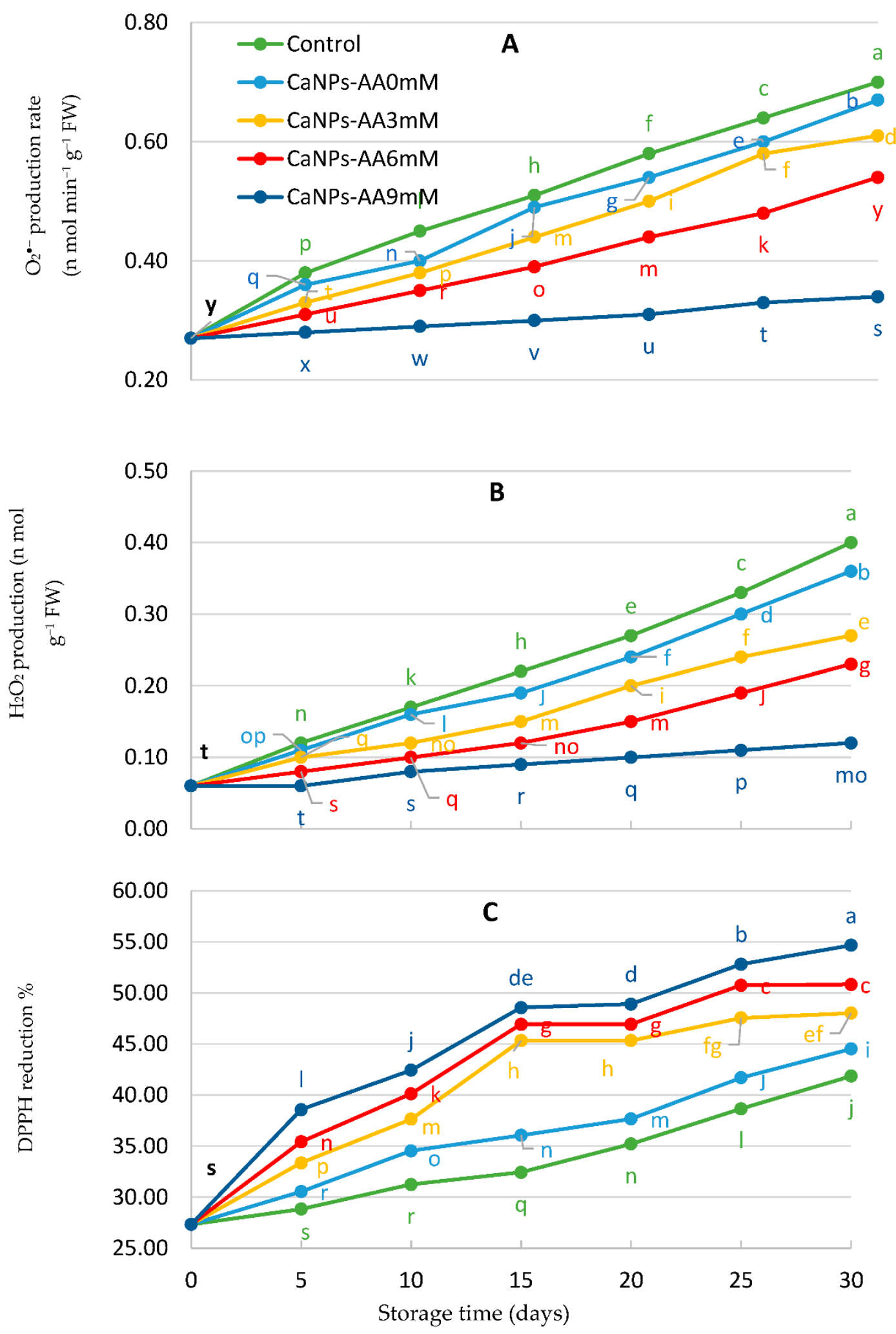

Figure 9. $\mathrm{H}_{2} \mathrm{O}_{2}$ (A), $\mathrm{O}_{2}{ }^{\bullet-}$ (B) production rates, and DPPH reduction (C) in 'Florida Prince' peaches immersed in CaNPs mixed with ascorbic acid at different concentrations $(0,3,6$, and $9 \mathrm{mM})$ and stored at a low temperature $\left(4^{\circ} \mathrm{C}\right.$ and $95 \%$ $\mathrm{RH})$ for 30 days. Error bars represent standard errors and different letters indicate significant differences at $p \leq 0.05$ among treatments for each storage period. 


\section{Discussion}

This study examined the effectiveness of CaNP-AA treatment for reducing chilling injury in peaches during cold storage. Chilling injury has been recognized as a physiological disorder caused by low temperatures [44]. A variation was observed during 30 days of cold storage stress in peach fruit. Usually, low temperatures generate reactive oxygen species (ROS) during long-term cold storage [43]. The most abundant ROS produced is the hydroxyl radical $(\cdot \mathrm{OH})$, which reacts with lipids and proteins of the plasma cell membrane [45]. Over a long period of cold storage, malondialdehyde (MDA) and protein carbonyl groups (PCG) terminate the lipid and protein of the cell membrane [46]. Consequently, cell membrane structure and function are lost [13] and cell death occurs [15]. With cell death, CI symptoms appear [45] via an equilibrium between ROS formation and antioxidant system activity under low temperatures $[15,19]$. Our results confirmed that the most severe symptoms of $\mathrm{CI}$ were observed in untreated fruit compared with CaNP-AA treatments. We observed that the $9 \mathrm{mM}$ CaNP-AA treatment minimized CI symptoms and water loss. These results were due to the efficacy of AA at $9 \mathrm{mM}$ for quenching ROS formation and preventing cell damage [15,47]. The reduction in CI incidence was reflected in fruit color (hue angle) (Figure 4). This may demonstrate that the presence of AA in combination with CaNP application preserved the water content during cold storage [48] The results are consistent with other previous studies on peaches [49,50], which confirmed the positive influence of CaNP-AA treatment on minimizing chilling injury symptoms and improving fruit quality during cold storage.

In the present study, $9 \mathrm{mM}$ CaNP-AA produced fewer changes in SSC and TA than other treatments (Figure 5). The SSC and TA remained at the same level as the initial values, which could be due to the role of $\mathrm{AA}$ as an antioxidant that decreased the oxidation reaction [51]. The SSC/TA ratio is an indicator of the good taste and flavor of peach fruit [52].

The changes in both SSC $\%$ and TA\% in stressed peach fruit during cold storage after CaNP-AA treatment can be attributed to the conversion of organic acids to sugar [53]. Moreover, the highest SSC \% seen throughout the storage period may have occurred as a consequence of decreasing AA and acidity under prolonged storage [17]. Furthermore, it could be associated with increases in starch enzyme activities that change organic acids to sugar, as described previously [54]. Similar results were observed in sweet orange fruit [55], lime [56], and pawpaw [57] stored at low temperatures.

The results revealed that fruit treated with $9 \mathrm{mM} \mathrm{CaNP}-\mathrm{AA}$ maintained better fruit pigmentation and fruit firmness than the control (Figure 6). Based on the fruit quality data, it is clear that with the $9 \mathrm{mM} \mathrm{L}^{-1}$ CaNP-AA treatment, no adverse effects were observed in the fruit. However, higher AA doses $\left(9 \mathrm{mM} \mathrm{L}^{-1}\right)$ were more effective at reducing the decline in peach quality. Thus, the $9 \mathrm{mM} \mathrm{CaNP-AA}$ application maintained the fruit pigments and firmness of peach fruit under cold storage. These findings may be linked to the physiological roles of calcium and AA in the CaNP-AA mixture. Calcium is essential for maintaining cell wall stability and integrity, as well as determining fruit quality [58]. Calcium has been demonstrated to be effective at preserving the quality of fruit [58], increasing antioxidant capacity [59], preventing softening [58], alleviating chilling injury [60], controlling postharvest decay [61], and delaying the fruit ripening process [62]. Previously, calcium lactate had better textural and sensory properties on peaches than calcium chloride and calcium propionate [58]. Supplementing CaNPs with AA provided additional benefits, such as quenching ROS [63], maintaining fruit quality throughout cold storage [64], delaying fruit ripening, and reducing microbial infection [65]. These results are in line with the findings of Campos-Vargas et al. [66] on 'O'Henry' peaches.

In our study, APX, CAT, GR, and SOD activities were more strongly activated in $9 \mathrm{mM}$ CaNP-AA-treated fruit. According to several reports, APX donates an electron to free radicals and converts $\mathrm{H}_{2} \mathrm{O}_{2}$ to oxygen and water, thereby mitigating oxidative damage [67]. The activity of the APX enzyme is directly proportional to the amount of AA [68]. Thus, the increased activity in $9 \mathrm{mM} \mathrm{CaNP}-\mathrm{AA}$-treated peaches could be a result of stable AA 
concentrations in the fruit. Additionally, findings have shown that both CAT and SOD are essential enzymes for reducing ROS damage in litchi fruit [69]. Reduced CAT and SOD activity are typically associated with increased fruit senescence [70]. The increased CAT and SOD activity may be attributed to the fruit treated with $9 \mathrm{mM} \mathrm{CaNP}-\mathrm{AA}$ producing fewer $\mathrm{O}_{2}{ }^{\bullet-}$ and $\mathrm{H}_{2} \mathrm{O}_{2}$ radicals. Their activities were enhanced with CaNP-AA treatments based on the concentration of AA. Certain differences in AEAs among the CaNP-AA applications can be revealed. The presence of AA in combination with CaNP mixture at a high concentration $(9 \mathrm{mM})$ improved AEAs during cold storage. The CaNPs also increased AA to quench ROS formation throughout storage [71]. However, the AA works indirectly as a quencher of ROS [27]. Moreover, AA might be forced to balance the production of ROS and AEAs [19]. Hence, AA can be used as a stabilizer of the network of AEAs [15]. The results are in line with other studies conducted on peach [49,72], persimmon fruit [73], and banana [44].

Calcium $\left(\mathrm{Ca}^{2+}\right)$ is an essential mineral for fruit and plays an important role in forming cell walls and membranes [74]. A second messenger in plant signal transduction, $\mathrm{Ca}^{2+}$ is implicated in stress responses [75]. Furthermore, different calcium-binding proteins perceive transitory increases in cytosolic $\mathrm{Ca}^{2+}$ under cold stress and trigger varied physiological responses [76]. Calcium in the form of $\mathrm{CaCl}_{2}$ treatment reduced peel browning caused by freezing injury in pear fruit by inhibiting membrane lipid peroxtion and increasing SOD activity and expression [77]. It reduced chilling injury symptoms in winter jujube fruit [78]. By modulating SOD, POD, CAT, and the AsA-GSH cycle, $\mathrm{CaCl}_{2}$ increased chilling tolerance in green peppers [79]. A previous study on loquat fruit found that $\mathrm{CaCl}_{2}$ treatment increased cold tolerance by regulating energy metabolism and accumulating osmotic substances [72,80].

In this work, MDA accumulation was the most prevalent side effect of lipid peroxidation, a process that can cause cellular membrane damage [81]. Elevated ROS levels can lead to more lipid peroxidation, leading to damaged membranes and decreased storage capacity [82]. Due to the reduction in oxidative damage and senescence, $9 \mathrm{mM} \mathrm{CaNP}-$ AA-treated peaches showed reduced MDA and IL \% concentrations. CaNPs were paired with AA to minimize ethylene and respiration. In this context, further investigations are required to determine how these two methods achieved such positive results.

The results were obtained due to the decline in oxygen-consuming respiration under cold storage, which diminishes both $\mathrm{H}_{2} \mathrm{O}_{2}$ and $\mathrm{O}_{2}{ }^{\bullet-}$ production [83]. Furthermore, the increase in AEAs (Figure 4) may diminish both the production of $\mathrm{H}_{2} \mathrm{O}_{2}$ and $\mathrm{O}_{2}{ }^{\bullet-}$ correlated with improved SOD activity, as indicated by Lo'ay and El-Khateeb [17]. The relationship between both CAT and APX in the network, besides other antioxidants [15], could be strongly connected to the quenching of both $\mathrm{H}_{2} \mathrm{O}_{2}$ and $\mathrm{O}_{2}{ }^{\bullet-}$ or the minimization of the effects of both [41].

\section{Conclusions}

CI significantly impairs the storage of peach fruits, as measured by fruit loss over the course of a cold storage period. The $9 \mathrm{mM} \mathrm{CaNP-AA}$ treatment clearly ameliorated $\mathrm{CI}$ in peach fruit by improving AEAs and minimizing ion leakage. Thus, treatment with $\mathrm{AA}$ at $9 \mathrm{mM} \mathrm{L}^{-1}$ together with CaNPs suppressed the incidence of CI during cold stress, particularly in terms of ROS. It also activated antioxidant enzymes, which was reflected by the low MDA content throughout the cold storage period. Our results suggest that a mixture of AA with CaNPs could be used as a tool adjuvant to maintain fruit quality traits under cold storage.

Author Contributions: Conceptualization, L.A.A.; data curation and validation, L.A.A.; methodology, L.A.A. and H.S.K.; formal analysis, L.A.A. and H.S.K.; writing-original draft preparation, L.A.A. and H.S.K.; writing-review and editing, H.I. All authors have read and agreed to the published version of the manuscript. 
Funding: This research was funded by Researchers Supporting Project Number (RSP-2021/403), King Saud University, Riyadh, Saudi Arabia.

Institutional Review Board Statement: Not applicable.

Informed Consent Statement: Not applicable.

Data Availability Statement: Data are contained within the article.

Conflicts of Interest: The authors declare no conflict of interest.

\section{References}

1. $\quad$ El-Boray, M.S.; Shalan, A.M.; Khouri, Z.M. Performance of Peach Trees cv. Florida Prince under Different Foliar Concentrations of NPK-humate in Presence or Absence of Adjuvants. Trends Hortic. Res. 2016, 6, 5-17.

2. FAOSTAT. Peach Production in Egypt; FAO: Rome, Italy, 2017.

3. Jin, P.; Zhu, H.; Wang, L.; Shen, T.; Zheng, Y. Oxalic acid alleviates chilling injury in peach fruit by regulating energy metabolism and fatty acid contents. Postharvest Biol. Technol. 2014, 161, 87-93. [CrossRef]

4. Wang, C.Y. Chilling Injury of Horticultural Crops; CRC Press: Boca Raton, FL, USA, 1990.

5. Lurie, S.; Crisosto, C.H. Chilling injury in peach and nectarine. Postharvest Biol. Technol. 2005, 37, 195-208. [CrossRef]

6. Brummell, D.A.; Dal Cin, V.; Crisoto, C.H.; Labavith, J.M. Cell wall metabolism during the development of chilling injury in cold-stored peach fruit: Association of mealiness with arrested disassembly of cell wall pectins. J. Exp. Bot. 2004, 55, 2041-2052. [CrossRef] [PubMed]

7. Cao, S.; Hu, Z.; Zheng, Y.; Lu, B. Synergistic effect of heat treatment and salicylic acid on alleviating internal browning in cold-stored peach fruit. Postharvest Biol. Technol. 2010, 58, 93-97. [CrossRef]

8. Fernandez-Trujillo, J.P.; Martinez, J.A.; Artes, F. Modified atmosphere pack affect the incidence of cold storage disorder and keep 'flat' peach quality. Food Res. Int. 1998, 31, 571-579. [CrossRef]

9. Ebel, R.C.; Woods, F.M.; Himelrick, D. Effect of UV-C on ripening and postharvest quality of peach. HortScience 1999, 34, 504. [CrossRef]

10. Feng, L.; Zheng, Y.H.; Zhang, Y.F.; Wang, F.; Zhang, L.; Lu, Z.X. Methyl jasmonate reduces chilling injury and maintains postharvest quality in peaches. Agric. Sci. China 2003, 11, 1246-1252.

11. Girardi, C.L.; Corrent, A.R.; Lucchetta, L.; Zanuzo, M.R.; Da Costa, T.S.; Brachmann, A.; Twymand, R.M.; Nora, F.R.; Nora, L.; Silva, J.A.; et al. Effect of ethylene, intermittent warming and controlled atmosphere on postharvest quality and occurrence of woolliness in peach (Prunus persic cv. Chiripa) during cold storage. Postharvest Biol. Technol. 2005, 38, 25-33. [CrossRef]

12. Wang, L.; Chen, S.; Kong, W.; Li, S.; Archbold, D.D. Salicylic acid pretreatment alleviates chilling injury and affects the antioxidant system and heat shock proteins of peaches during cold storage. Postharvest Biol. Technol. 2006, 41, 244-251. [CrossRef]

13. Lo'ay, A.A.; Ameer, N.M. Performance of calcium nanoparticles blending with ascorbic acid and alleviation internal browning of 'Hindi Be-Sennara' mango fruit at a low temperature. Sci. Hortic. 2019, 254, 199-207. [CrossRef]

14. Wismer, W.V.; Worthing, W.M.; Yada, R.Y.; Marangoni, A.G. Membrane lipid dynamics and lipid peroxidation in the early stages of low-temperature sweetening in tubers of Solanum tuberosum. Physiol. Plant. 1998, 102, 396-410. [CrossRef]

15. Foyer, C.H.; Ruban, A.V.; Noctor, G. Viewing oxidative stress through the lens of oxidative signaling rather than damage. Biochem. J. 2017, 474, 877-883. [CrossRef] [PubMed]

16. Hossain, Z.; Nouri, M.Z.; Komatsu, S. Plant Cell Organelle Proteomics in Response to Abiotic Stress. J. Proteome Res. 2012, 11, 37-48. [CrossRef] [PubMed]

17. Lo'ay, A.A.; El-Khateeb, A.Y. Antioxidant enzyme activities and exogenous ascorbic acid treatment of 'Williams' banana during long-term cold storage stress. Sci. Hortic. 2018, 234, 210-219. [CrossRef]

18. Purvis, A.C. Regulatin of oxidative stress in horticultural crops. HortiScience 2004, 39, 930-932. [CrossRef]

19. Foyer, C.H.; Noctor, G. Oxidant and antioxidant signalling in plants: A re-evaluation of the concept of oxidative stress in a physiological context. Plant Cell Environ. 2005, 28, 1056-1071. [CrossRef]

20. Manganaris, G.A.; Vasilakakis, M.; Diamantidis, G.; Mignani, I. Effect of calcium additives on physicochemical aspects of cell wall pectin and sensory attributes of canned peach (Prunus persica Batsch cv Andross). J. Sci. Food Agric. 2005, 85, 1773-1777. [CrossRef]

21. Fan, X.; Niemera, B.A.; Matthheis, J.P.; Zhuang, H.; Olson, D.W. Quality of fresh-cut apple slices as affected by low-dose ionizing radiation and calcium ascorbate treatment. J. Food Sci. 2005, 70, 143-149. [CrossRef]

22. Luna-Guzman, I.; Cantwell, M.; Barrett, D.M. Fresh-cut cantaloupe: Effects of calcium chloride dips and heat treatments on firmness and metabolic activity. Postharvest Biol. Technol. 1999, 17, 201-213. [CrossRef]

23. Mishra, S. Calcium Chloride Treatment of Fruits and Vegetables; Tetre Technologies Inc.: The Woodlands, TX, USA, 2002.

24. Yugandhar, P.; Savithramma, N. Biosynthesis, characterization and antimicrobial studies of green synthesized silver nanoparticles from fruit extract of Syzygium alternifolium (Wt.) Walp. an endemic, endangered medicinal tree taxon. Appl. Nanosci. 2016, 6, 223-233. [CrossRef]

25. Schirra, M. Behaviour of 'star Ruby' grapefruit under chilling and non-chilling storage temperature. Postharvest Biol. Technol. 1992, 2, 315-327. [CrossRef] 
26. Khojastehnazhand, M.; Omid, M.; Tabatabaeefar, A. Development of a lemon sorting system based on color and size. Afr. J. Plant Sci. 2010, 4, 122-127.

27. Lo'ay, A.A.; Dawood, H.D. Active chitosan/PVA with ascorbic acid and berry quality of 'Superior seedless' grapes. Sci. Hortic. 2017, 224, 286-292. [CrossRef]

28. Mehrtens, F.; Kranz, H.; Bednarek, P.; Weisshaar, B. The Arabidopsis Transcription Factor MYB12 Is a Flavonol-Specific Regulator of Phenylpropanoid Biosynthesis. Plant Physiol. 2005, 138, 1083-1096. [CrossRef] [PubMed]

29. Mínguez-Mosquera, M.I.; Jarén-Galán, M.; Hornero-Méndez, D.; Garrido-Fernández, J.; Gallardo-Guerrero, M.L.; Gandul-Rojas, B. Decoloration of vegetable oils and oleoresins with recovery of unaltered pigments. J. Am. Oil Chem. Soc. 1991, 68, 809-813. [CrossRef]

30. Biehler, E.; Mayer, F.; Hoffmann, L.; Krause, E.; Bohn, T. Comparison of 3 Spectrophotometric Methods for Carotenoid Determination in Frequently Consumed Fruits and Vegetables. J. Food Sci. 2010, 75, C55-C61. [CrossRef] [PubMed]

31. Wang, J.; Teng, B.; Yu, Y. The firmness detection by excitation dynamic characteristics for peach. Food Control 2006, 17, 353-358. [CrossRef]

32. Kar, M.; Mishra, D. Catalase, peroxidase, and polyphenoloxidase activities during rice leaf senescence. Plant Physiol. 1976, 57, 315-319. [CrossRef]

33. Asada, K. Assay of ascorbate-specific peroxidase. Methods Enzymol. 1984, 105, 427-429.

34. Smith, I.S.; Vierheller, T.L.; Thorne, C.A. Assay of glutathione reductase in crude tissue homogenates using 5,5\%-dithiobis (2-nitrobenzoic acid). Anal. Biochem. 1988, 175, 408-413. [CrossRef]

35. Carlberg, I.; Mannervik, B. Glutathione reductase. Methods Enzymol. 1985, 113, 484-490.

36. Oberley, L.W.; Spitz, D.R. Nitroblue tetrazolium. In Handbook of Methods for Oxygen Radical Research; Greenwald, R.A., Ed.; CRC Press: Boca Raton, FL, USA, 1986.

37. Bradford, M.M. A rapid and sensitive method for the quantitation of microgram quantities of protein utilizing the principle of protein-dye binding. Anal. Biochem. 1976, 72, 248-254. [CrossRef]

38. Iturbe-Ormaetxe, I.; Escuredo, P.R.; Arrese-Igor, C.; Becana, M. Oxidative damage in pea plants exposed to water deficit or paraquat. Plant Physiol. 1998, 116, 173-181. [CrossRef]

39. Lo'ay, A.A.; Taha, N.A.; El-Khateeb, Y.A. Storability of 'Thompson Seedless' grapes: Using biopolymer coating chitosan and polyvinyl alcohol blending with salicylic acid and antioxidant enzymes activities during cold storage. Sci. Hortic. 2019, 249, 314-321. [CrossRef]

40. Lo'ay, A.A. Chilling Injury in Mangoes. Ph.D. Thesis, Wageningen University, Wageningen, The Netherlands, 2005.

41. Yang, H.; Wu, F.; Cheng, J. Reduced chilling injury in cucumber by nitricoxide and the antioxidant response. Food Chem. 2011, 127, 1237-1242. [CrossRef]

42. Xu, M.; Dong, J.; Zhang, M.; Xu, X.; Sun, L. Cold-induced endogenous nitric oxide generation plays a role in chilling tolerance of loquat fruit during postharvest storage. Postharvest Biol. Technol. 2012, 65, 5-12. [CrossRef]

43. Yen, G.C.; Chen, H.Y. Antioxidant activity of various tea extracts in relation to their antimutagenicity. J. Agric. Food Chem. 1995, 43, 27-32. [CrossRef]

44. Chen, L.-L.; Shan, W.; Cai, D.-L.; Chen, J.-Y.; Lu, W.-J.; Su, X.-G.; Kuang, J.-F. Postharvest application of glycine betaine ameliorates chilling injury in cold-stored banana fruit by enhancing antioxidant system. Sci. Hortic. 2021, 287, 110264. [CrossRef]

45. Lo'ay, A.A.; Doaa, M.H. The potential of vine rootstocks impacts on 'Flame Seedless' bunches behavior under cold storage and antioxidant enzyme activity performance. Sci. Hortic. 2020, 260, 108844. [CrossRef]

46. Hodges, D.M.; Lester, G.E.; Munro, K.D.; Toivonen, P.M.A. Oxidative stress: Importance for postharvest quality. HortScience 2004, 39, 924-929. [CrossRef]

47. Wang, C.Y. Reducing chilling injury and maintaining quality of horticultural crops with natural products and their derivatives. Acta Hortic. 2006, 712, 285-290. [CrossRef]

48. Kondo, S.; Kittikorn, M.; Kanlayanarat, S. Preharvest antioxidant activities of tropical fruit and the effect of low temperature storage on antioxidants and jasmonates. Postharvest Biol. Technol. 2005, 36, 309-318. [CrossRef]

49. Liu, H.; Jiang, W.; Cao, J.; Ma, L. A combination of 1-methylcyclopropene treatment and intermittent warming alleviates chilling injury and affects phenolics and antioxidant activity of peach fruit during storage. Sci. Hortic. 2018, 229, 175-181. [CrossRef]

50. Zhu, L.Q.; Zhou, J.; Zhu, S.H. Effect of a combination of nitric oxide treatment and intermittent warming on prevention of chilling injury of 'Feicheng' peach fruit during storage. Food Chem. 2010, 121, 165-170. [CrossRef]

51. Giménez, M.; Olarte, C.; Sanz, S.; Lomas, C.; Echávarri, J.F.; Ayala, F. Influence of Packaging Films on the Sensory and Microbiological Evolution of Minimally Processed Borage (Borrago officinalis). J. Food Sci. 2003, 68, 1051-1058. [CrossRef]

52. De Reuck, K.; Sivakumar, D.; Korsten, L. Integrated application of 1-methylcyclopropene and modified atmosphere packaging to improve quality retention of litchi cultivars during storage. Postharvest Biol. Technol. 2009, 52, 71-77. [CrossRef]

53. Baldwin, E.A.; Niesperos, M.O.; Shaw, P.E.; Burns, J.K. Effect of coatings and prolonged storage conditions on fresh orange flavour volatiles, degrees brix and ascorbic acid levels. J. Agric. Food Chem. 1995, 43, 1321-1331. [CrossRef]

54. Kader, A.A. Postharvest Technology of Horticulture Crops, 3rd ed.; University of California Agriculture \& Natural Resources: Irvine, CA, USA, 2002.

55. Shahid, M.N.; Abbasi, N.A. Effect of bee wax coatings on physiological changes in fruits of sweet orange CV. "Blood Red". Sarhad J. Agric. 2011, 27, 385-394. 
56. Verma, P.; Dashora, L.K. Post-harvest physiconutritional changes in Kagzi Limes (Citrus aurantifolia S.) treated with selected oil emulsions and diphenyl. Plant Food Hum. Nutr. 2000, 55, 279-284. [CrossRef]

57. Galli, F.; Archbold, D.D.; Pomper, K.W. Pawpaw fruit chilling injury and antioxidant protection. J. Am. Soc. Hortic. Sci. 2009, 134, 466-471. [CrossRef]

58. Wang, Y.; Long, L.E. Physiological and biochemical changes relating to postharvest splitting of sweet cherries affected by calcium application in hydrocooling water. Food Chem. 2015, 181, 241-247. [CrossRef] [PubMed]

59. Naser, F.; Rabiei, V.; Razavi, F.; Khademi, O. Effect of calcium lactate in combination with hot water treatment on the nutritional quality of persimmon fruit during cold storage. Sci. Hortic. 2018, 233, 114-123. [CrossRef]

60. Gerasopoulos, D.; Drogoudi, P.D. Summer-pruning and preharvest calcium chloride sprays affect storability and low temperature breakdown incidence in kiwifruit. Postharvest Biol. Technol. 2005, 36, 303-308. [CrossRef]

61. Sugar, D.; Basile, S.R. Orchard calcium and fungicide treatments mitigate effects of delayed postharvest fungicide applications for control of postharvest decay of pear fruit. Postharvest Biol. Technol. 2011, 60, 52-56. [CrossRef]

62. Madani, B.; Mohamed, M.T.M.; Watkins, C.B.; Kadir, J.; Awang, Y.; Shojaei, T.R. Preharvest calcium chloride sprays affect ripening of Eksotika II'papaya fruits during cold storage. Sci. Hortic. 2014, 171, 6-13. [CrossRef]

63. Fang, T.; Zhen, Q.; Liao, L.; Owiti, A.; Zhao, L.; Korban, S.S.; Han, Y. Variation of ascorbic acid concentration in fruits of cultivated and wild apples. Food Chem. 2017, 225, 132-137. [CrossRef]

64. Lin, L.; Li, Q.P.; Wang, B.G.; Cao, J.K.; Jiang, W.B. Inhibition of core browning in 'Yali' pear fruit by post-harvest treatment with ascorbic acid. J. Hortic. Sci. Biotechnol. 2007, 82, 397-402. [CrossRef]

65. Sogvar, O.B.; Koushesh Saba, M.; Emamifar, A. Aloe vera and ascorbic acid coatings maintain postharvest quality and reduce microbial load of strawberry fruit. Postharvest Biol. Technol. 2016, 114, 29-35. [CrossRef]

66. Campos-Vargas, R.; Becerra, O.; Baeza-Yates, R.; Cambiazo, V.; González, M.; Meisel, L.; Orellana, A.; Retamales, J.; Silva, H.; Defilippi, B.G. Seasonal variation in the development of chilling injury in 'O'Henry' peaches. Sci. Hortic. 2006, 110, 79-83. [CrossRef]

67. Gupta, A.S.; Webb, R.P.; Holaday, A.S.; Allen, R.D. Overexpression of Superoxide Dismutase Protects Plants from Oxidative Stress (Induction of Ascorbate Peroxidase in Superoxide Dismutase-Overexpressing Plants). Plant Physiol. 1993, 103, $1067-1073$. [CrossRef] [PubMed]

68. Elia, M.R.; Borraccino, G.; Dipierro, S. Soluble ascorbate peroxidase from potato tubers. Plant Sci. 1992, 85, 17-21. [CrossRef]

69. Duan, X.; Liu, T.; Zhang, D.; Su, X.; Lin, H.; Jiang, Y. Effect of pure oxygen atmosphere on antioxidant enzyme and antioxidant activity of harvested litchi fruit during storage. Food Res. Int. 2011, 44, 1905-1911. [CrossRef]

70. Ali, S.; Khan, A.S.; Malik, A.U.; Shahid, M. Effect of controlled atmosphere storage on pericarp browning, bioactive compounds and antioxidant enzymes of litchi fruits. Food Chem. 2016, 206, 18-29. [CrossRef]

71. Rapisarda, P.; Bianco, M.L.; Pannuzzo, P.; Timpanaro, N. Effect of cold storage on vitamin C, phenolics and antioxidant activity of five orange genotypes [Citrus sinensis (L.) Osbeck]. Postharvest Biol. Technol. 2008, 49, 348-354. [CrossRef]

72. Hou, Y.; Li, Z.; Zheng, Y.; Jin, P. Effects of $\mathrm{CaCl}_{2}$ Treatment Alleviates Chilling Injury of Loquat Fruit (Eribotrya japonica) by Modulating ROS Homeostasis. Foods 2021, 10, 1662. [CrossRef]

73. Niazi, Z.; Razavi, F.; Khademi, O.; Aghdam, M.S. Exogenous application of hydrogen sulfide and $\gamma$-aminobutyric acid alleviates chilling injury and preserves quality of persimmon fruit (Diospyros kaki, cv. Karaj) during cold storage. Sci. Hortic. 2021, 285, 110198. [CrossRef]

74. Hocking, B.; Tyerman, S.D.; Burton, R.A.; Gilliham, M. Fruit Calcium: Transport and Physiology. Front. Plant Sci. 2016, 7, 569. [CrossRef]

75. Ranty, B.; Aldon, D.; Cotelle, V.; Galaud, J.-P.; Thuleau, P.; Mazars, C. Calcium Sensors as Key Hubs in Plant Responses to Biotic and Abiotic Stresses. Front. Plant Sci. 2016, 7, 327. [CrossRef]

76. Yuan, P.; Yang, T.; Poovaiah, B.W. Calcium Signaling-Mediated Plant Response to Cold Stress. Int. J. Mol. Sci. 2018, 19, 3896. [CrossRef]

77. Zhang, L.; Wang, J.-W.; Zhou, B.; Li, G.-D.; Liu, Y.-F.; Xia, X.-L.; Xiao, Z.-G.; Fei, L.; Ji, S.-J. Calcium inhibited peel browning by regulating enzymes in membrane metabolism of 'Nanguo' pears during post-ripeness after refrigerated storage. Sci. Hortic. 2019, 244, 15-21. [CrossRef]

78. Wei, D.; Zhao, X.-h. Calcium maintained higher quality and enhanced resistance against chilling stress by regulating enzymes in reactive oxygen and biofilm metabolism of Chinese winter jujube fruit. J. Food Biochem. 2020, 44, 13161. [CrossRef] [PubMed]

79. Zhang, X.; Ma, M.; Ye, B.; Liu, L.; Ji, S. Calcium ion improves cold resistance of green peppers (Capsicum annuum L.) by regulating the activity of protective enzymes and membrane lipid composition. Sci. Hortic. 2021, 277, 109789. [CrossRef]

80. Li, Z.; Wang, L.; Xie, B.; Hu, S.; Zheng, Y.; Jin, P. Effects of exogenous calcium and calcium chelant on cold tolerance of postharvest loquat fruit. Sci. Hortic. 2020, 269, 109391. [CrossRef]

81. Wang, C.F.; Cheng, Z.M.; Li, Y. Effect of postharvest treatments on physiology and quality of litchi and their economics. Acta Hortic. 1996, 429, 503-507. [CrossRef]

82. Shewfelt, R.L.; del Rosario, B.A. The role of lipid peroxidation in storage disorders of fresh fruits and vegetables. HortScience 2000, 35, 575-579. [CrossRef]

83. Tang, T.; Huang, D.W.; Zhou, C.Q.; Li, X.; Xie, Q.J.; Liu, F.S. Molecular cloning and expression patterns of copper/zinc superoxide dismutase and manganese superoxide dismutase in Musca domestica. Gene 2012, 505, 211-220. [CrossRef] 